\title{
Sharp van der Heijde Bone Erosion Score
}

National Cancer Institute

\section{Source}

National Cancer Institute. Sharp van der Heijde Bone Erosion Score. NCI Thesaurus.

Code C128988.

The numerical value that represents the result of a clinical assessment of bone erosion based on the Van der Heijde modification of the Sharp Joint Erosion Assessment (Van der Heijde DM, van Riel PL, Nuver-Zwart IH, Gribnau FW, van de Putte LB. Effects of hydroxychloroquine and sulphasalazine on progression of joint damage in rheumatoid arthritis. Lancet 1989;1:1036-8). 